\title{
Vulnerability as a Key Concept in Museum Pedagogy on Difficult Matters
}

\author{
Katrine Tinning ${ }^{1}$
}

Published online: 4 October 2017

(C) The Author(s) 2017. This article is an open access publication

\begin{abstract}
In recent years there has been an increasing interest in museum studies in exhibitions on what is termed Difficult Matters (Silvén and Björklund 2006)—such as rape and mass murder-and how such exhibitions may evoke ethical change. This raises the question about the conditions on which such exhibitions can lead to an ethical change. By developing a conceptual framework this article contributes to museum studies on Difficult Matters demonstrating how vulnerability can work as a key concept in a relational pedagogical understanding of the conditions for ethical change. Inspired by feminist ethics the article suggests that there is an "ambivalent potentiality" of the concept of vulnerability (Murphy, in Violence and the philosophical imaginary, State University of New York Press, Albany, 2012) and forwards a double perspective on vulnerability as condition: vulnerability is inherent to the human condition and always situational. From this point of departure vulnerability is fleshed out as a key concept in museum pedagogy via pedagogical thinkers inspired by the philosopher Emmanuel Lévinas' ethics. Concepts like heteronomy, incarnation, Face and Saying/Said are introduced to define vulnerability and the relation between exhibition and visitor is defined as a teaching-learning relation conditioned by vulnerability. Vulnerability is defined as openness to an encounter with the Other as being different, which is conditional of an ethical transformation of existing perceptions of self, others and the world. Finally, inspired by feminist philosophy (Butler, in Precarious life the powers of mourning and violence, Verso, London, 2006) a norm critical is introduced. It is argued that displaying Difficult Matters in order to evoke an ethical transformation museum professionals need consider critically the norms of vulnerability at play in particular situations. On this basis, the concept of vulnerability can serve as a lever for discussions on the pedagogy of exhibitions on Difficult Matters and the ethical responsibility of museum professionals in public museums in this regard.
\end{abstract}

Katrine Tinning

katrine.tinning@soc.lu.se

1 Division for Education, Department of Sociology, Lund University, Paradisgatan 5, 22100 Lund, Sweden 
Keywords Museum pedagogy - Difficult Matters - Vulnerability · Ethics of vulnerability · Teaching-learning relation $\cdot$ Emmanuel Lévinas

In 2006 Silvén and Björklund open the discussion on Difficult Matters in museum studies in Sweden with their book Difficult Matters. Objects and Narratives that Disturb and Affect. The book built on experiences from a travelling exhibition-a mobile trailer containing 54 objects-moving through Sweden in 1999-2000. The design of the exhibit was a response to a perceived lack of attention to the "darker sides" of cultural heritage. The designers wondered "who saves objects that testify to the obscene, to what is dirty and disgusting, to the politically dangerous?' (Silvén \& Björklund 2006, 249). Swedish museums were asked to contribute to the exhibit and select objects from their collections which they found were difficult in the meaning of evoking 'thoughts of a different reality from the well ordered "normality" (Silvén \& Björklund 2006, 249).

Exhibiting Difficult Matters in the museum raises a set of ethical issues to museum professionals. Introducing the concept of vulnerability in museology offers the opportunity of developing existing understandings of ethical and pedagogical challenges involved in displaying Difficult Matters. By clarifying and re-defining the difficulties of exhibiting it becomes possible to discuss the ambivalent potential of representing and learning from Difficult Matter-how it may become an opening to growth as well as to harm. It underscores how curatorial practice and visitor involvement are pedagogical issues which are intimately linked to the question of ethical responsibility.

While some studies primarily look at the difficulties of Difficult Matters as being connected to the universal condition of openness to the Other and as concerning a general experience of "being touched" (Simon e.g. 2000, 2005, 2014), others focus on difficulties of particular socio-cultural situations of involvement with such matters (Silvén and Björklund 2006). The double perspective put forward for consideration in the article integrates the insights into the condition of openness to the other, which must be viewed as inherent and as situational. It also develops the notion of openness to an encounter with the Other as a possibility of "being touched", which must be considered in relation to an ethical transformation of self, others and the world, i.e. as a transformative learning experience. It points out that vulnerability as openness is the basis for "being touched" and as such it is a matter of heteronomy as the learning experience of the other, which evokes an ethical transformation, depends on the teaching of the Other. The concept of incarnation develops the understanding of embodied experience of being touched in regard to ethical transformation, and the concepts of Face and Saying/Said offer a path for museum professionals to critically discuss the difficulties of representing, communicating or depicting Difficult Matters.

The article follows Simon's assumption (2011) that exhibitions on Difficult Matters are associated with pedagogical issues, but expands the understanding by developing the concept of teaching-learning relationships as being contingent upon vulnerability. It underscores that both poles in the pedagogical relationship — teaching and learning-must be considered critically in relation to exhibitions on Difficult Matters. When Simon addresses the pedagogy of witnessing historical trauma in museums, he talks about visitors' involvement in terms of learning, but uses the term of curatorial practice instead of teaching (Simon 2014). Basically, viewing curatorship as a pedagogical activity, the article suggests that the concepts of teaching and learning are used consistently. The focus on the 
two poles of the pedagogical "entanglement" contributes to a development of a relational perspective, which Witcomb (2013) maintains is of central importance to understanding processes of change in relation to Difficult Matters. Linking the visitors' experience of "empathic unsettlement" in and by the encounter with Difficult Matters (Witcomb 2013) to an idea of transformation is important in order to counteract the risk exhibitions on Difficult Matters leading to "empty empathy" (Zembylas 2014). The problem entailed is that the exhibition may tickle visitors-produce a lightly touch in a way that causes mild discomfort-but lead to no substantial change after all. In the article a relational perspective on processes of change becomes linked to a pedagogical philosophical and ethical level, which Witcomb does not do, but which helps defining the conditions of change and determining change more precisely in terms of ethical transformation of existing perception of self, others and the world.

It is generally assumed that Difficult Matters affect visitors: Simon talks about "the touch of the past" (2005) and Silvén and Björklund about Difficult Matters that affect. The advantage of Simon's intervention into museum pedagogy is that he frames the experience of "being touched" as a pedagogical matter and inspires the idea of being-affected or touched in the double meaning of sensuous-affective contact and ethical caring-for. The article develops this idea further via the concept of vulnerability of incarnated being grounding the understanding of the predicament of embodiment in museum pedagogy and offering concepts to discuss the opening to inspiration and the non-conscious and conscious layers of teaching and learning.

It appears, then, that exhibitions on Difficult Matters raise a number questions about ethical transformation in museum pedagogy and that vulnerability can act as a prism for museum professionals to look at these. With the notions of heteronomy, incarnation, face/ saying/said, the stage is set for discussions in museum pedagogy on the complexity of representing the Other in order to evoke an ethical change. While the condition of vulnerability is put at the centre of teaching-learning relations as the possibility for a moment of opening of being to the other and thus to inspiration of ethical transformation of perceptions of self, others and the world, it is also shown that teaching-learning relations are permeated by social norms. Thus, the article connects to Witcomb's assumption (e.g. 2013) that the encounter with the other, which evokes an experience of the other as signifying beyond existing frames of meaning and language, must be seen also as being in some kind of contact with existing horizons of meaning. With the concepts of Face and Saying/Said as well as the norm critical perspective, the article contributes to the debate on Difficult Matters in museum studies and provides a conceptual framework for discussions among museum professionals about their ethical responsibility for the other's vulnerability when staging teaching-learning relations in exhibits on Difficult Matters.

In the following, the article first describes the emergence of the field of Difficult Matters in museum studies situating the case of Difficult Matters in the larger context of New Museology and the debates on learning and representation. It introduces what is "difficult" in the term Difficult Matters and how it relates to the notion of difficult knowledge in pedagogy giving a brief genealogy of the terms. On this basis, it is argued that the concept of vulnerability offers new opportunities for museum pedagogy for approaching exhibitions on Difficult Matters. Secondly, the concept of vulnerability is unfolded in a double perspective. The understanding of vulnerability as inherent to the human condition and as such to teaching and learning is defined via pedagogical thinkers inspired by Emmanuel Lévinas, and the view on situational vulnerability is developed via feminist ethics of vulnerability's call for a norm critical view (Butler 2006). 


\section{The Emergence of the Debate on Difficult Matters}

Evolving around the responsibility of the museum for the representation and learning opportunities it offers to the public the studies Difficult Matters (e.g. Silvén and Björklund 2006; Cameron and Kelly 2010) connect to the debates of so-called New Museologywhich is no longer that "new". 1

\section{New Museology and the Issues of Representation and Learning}

In the early stages of New Museology the focal point was a critique of the Modern Museum as a museum associated with the modern era and the rise of the nation state-a museum defined as being authoritarian, in favour of the institution and its message and enforcing visitors' obedience to the authority of the state while giving little attention to the visitor as an agent (Bennett 1995). Here a socio-cultural and societal view on the relation between museum, state, and citizen is developed and helps to shed a new light on museums as educational institutions in society. The Modern Museum is seen as extension of the state, which uses cultural history and heritage as educational tools for exercising power and control of visitors/the public: "it (the museum) deploys its machinery of representation within an apparatus whose orientation is primarily governmental" (Bennett 1995, 46).

The basic assumption is that power and knowledge go hand in hand and that museums are not neutral arenas that convey objective knowledge, but places that use representations of a historical past as a tool for evoking special forms of self-conduct for (state-) purpose. It is even shown how the museum reproduces social structures demanding certain cultural capital and habitus in visitors' engagement with heritage (Bourdieu and Darbel 1991) and that the museum is a powerful ritual space in society (Duncan 1995), where visitors can celebrate and become familiar with heritage in a ceremonial way in a prescribed order.

New Museology becomes a response to a perceived need for re-thinking the museum as an educational institution (Andersson 2005), and the focus is now on visitors' learning (e.g. Hooper-Greenhill 1994, 2007) and the social responsibilty of museums (Sandell 2003). Learning, inclusion, and representation become key words in defining the hope for a new relation between museum and visitors in which the museum is to emerge as the "contact zone" (Clifford 1997) and "forum" rather than a temple for admiration of exemplary heritage (Chinnery 2012). Still, the museum is imagined as the place which makes various groups and individuals connect by fostering them to become democratic citizens. Museums are, for example, envisioned as being responsible for teaching about the past in ways which inspire and open the public to re-imagination, to "the future we desire" (Janes 2007).

Hooper-Greenhill (e.g. 1994, 2007) and George Hein (1998) introduce constructive learning theory in museum studies, which becomes an influential frame of reference for visitors' processes of meaning-making. Hooper-Greenhill (1994) connects the notion of constructive learning to critical pedagogy showing that learning may lead to empowerment of visitors enforcing their "identity-building" as citizens.

The constructivist perspective on learning is also merged into socio-cultural theories of learning that help show how learning in the museum must be understood as a contextual and relational phenomenon aimed at making meaning in the world - as an infinite dialogue between the learner and the physical and socio-cultural surroundings (Falk and Dierking $(1992,2013)$. The new perspectives on learning are important to the re-thinking of museum

1 The term "New Museology" was introduced by Peter Vergo in (1989) in the book entitled The New Museology, London: Reaction Books. 
pedagogy and meaning-making in the arena of museum exhibitions, because they show that museum pedagogy, while it may be turned into a socio-political machine for governmentality (along state objectives), it may also assume the role of facilitator of visitors' active processes of identity building and participation in society.

Further, museum studies show that the responsibility of museums for teaching ethics and the visitors' relational learning, which evoke ethical responsibility is connected to the response given to "the other" in museums' representation and inclusion and visitors' participation in exhibition contexts. In Western societies which are increasingly being seen as multicultural the need to respond to diversity and difference will be a long-lasting issue in New Museology to be discussed (Acuff and Evans 2014; Johansson 2015). While acknowledging the need for including otherwose excluded individuals and groups, the difficulties of representing the other-and the ethical and normative issues involved-are still troubling; e.g. Sandell argues that representation in museums in multicultural society is dependent on the ability of museums to subvert dominant (discriminatory, oppressive, stereotypical) representations of the other and represent more diverse narratives (Sandell 2011). This suggests that there is something to be gained from developing a norm critical level in museum studies. Also, in order to understand how processes of subversion of existing-dominant-views can become transformative the level of pedagogy has something to offer, because pedagogy is the activity which is concerned with creating a change. Developing the relational pedagogical level can enhance the understanding of conditions for teaching ethics and learning from the other in ways that are responsive to diversity and difference and evoke change.

Although New Museology since its rise and first cycles has spread into many branches, which help highlight many different aspects of representation and involvement in museums such as affect (Watson 2016; Witcomb 2013), body (Leahy 2012), materiality (Dudley 2010) and gender (Hein 2011a, b) so that it may no longer be meaningful to speak of an overall paradigm, many museum studies still relate to the issue of the ethical responsibility of museum professionals for how they communicate, teach or represent the other in exhibitions, and the learning experiences of the visitor in relation to the other remains a central issue in museum studies. This is illustrated by the case of museum studies on Difficult Matters.

\section{What are the Difficulties and Possibilities of Displaying Difficult Matters?}

Studies on Difficult Matters continue in the footsteps of New Museology concerning the issue of the responsibility of the museum for representing and including a variety of people, narratives, and objects in ways which teach about the past and "open a future", but demonstrate that there are matters which are difficult to represent, include and communicate in the public space of museums. Silvén and Björklund (2006) talk about Difficult Matters and associate the difficult to how it may evoke thoughts of a different reality-a life that goes beyond the limits of general norms, conventions and standards. In this article I use the term Difficult Matters as a point of departure, yet develop the understanding of the difficulties involved.

In other recent museum studies Difficult Matters have been addressed in terms of e.g. challenging history (Kidd et al. 2014), difficult knowledge (Lehrer et al. 2011; Simon 2005, 2006, 2014), hot topics (Cameron and Kelly 2010), difficult heritage (Macdonald 2009), difficult histories (Rose 2016), difficult exhibitions or difficult histories (Witcomb 2010, 2013) or objectification of suffering (Williams 2011). Despite the different ways of naming the issue, it is a shared assumption that these matters are normally marginalised or 
excluded from public life, but also that museums have an ethical responsibility for representing these matters in their exhibitions, because museums-as societal institutionsmust be representative of all kinds of experiences and events in society.

It is generally assumed that such matters evoke experiences of risk, danger, loss of security, and exposure on the part of visitors-experiences which are normally seen as negative - and also challenge visitors' conceptual framework of understanding (Simon et al. 2000; Simon 2005, 2014; Cameron and Kelly 2010; Lehrer et al. 2011, Kidd et al. 2014). Rather than defining Difficult Matters as a heritage to be celebrated as an established ceremonial practice, they are discussed as scare images of suffering, pain, trauma and inhumanity.

What can visitors possibly gain from an involvement in exhibitions on such Difficult Matters? It is generally assumed that exhibitions on Difficult Matters can work as a kind of ethical transformative "tool" as they may act as an instigation to active participation in the present in creating a more responsible future social life. For example, Williams-in his discussion of Holocaust memorial museums-argues that: "with a common mission to prevent future horrific suffering - the 'never again' imperative instigated by Holocaust remembrance-memorial museums attempt to mobilize visitors as both historical witnesses and agents of present and future political vigilance" $(2011,220)$. Here the aspiration of museums to perform an ethical demand to visitors to "prevent suffering" is connected to a hope for civic engagement.

If heritage in the Modern Museum was used as "the social glue", which binds society together and creates social stability and harmony in accordance with certain intereststhen Holocaust is here presented as the "social glue" pasting together people in joint action towards a better world. However, Cameron and Kelly in defining what they term "hot topics" as matters, which are forbidden in social discourse and practice and which stimulate revision of attitudes to existing and accepted situations and points of view, find such topics give rise to public disagreement and conflict (Cameron and Kelly 2010). The perspective prolongs the socio-cultural, political, and societal perspectives on museums of New Museology.

On the level of pedagogical thinking, in his critical pedagogy of remembrance and witnessing of historical trauma, Roger I. Simon throughout his career develops a pedagogical and ethical perspective on what he terms Difficult Knowledge. He takes inspiration from Emmanuel Lévinas' ethics and from Deborah Britzman's psychoanalytical approach.

Britzman introduced the term difficult knowledge in pedagogy arguing that it "requires educators to think carefully about their own theories of learning and how stuff of such difficult knowledge becomes pedagogical" (Britzman 1998, 117). Three issues are of central importance in Britzman's theorization of what makes difficult knowledge difficult. First, the difficulties of representation: representations can never signify completely or adequately the events and experiences of difficulty (1998). Secondly, difficult knowledge is not only about a traumatic social event, but connected to the learner's own psychic history (1998, 119) - the encounter between the individual inside and an outside makes the learner experience an affective dissonance (i.e. negative emotions), which leads to feelings of loss (of meaning, of agency, of emotional tranquillity), which makes the learner struggles to learn from this loss $(2000,202)$, i.e. the difficult is traumatic and what makes trauma traumatic is "the incapacity to respond adequately, accompanied by the feelings of profound helplessness and loss, and the sense that no other group or person will intervene. What makes trauma traumatic is the loss of self and other". Simon picks up this thread arguing that $(2011,434)$ : "Difficulty happens when one's conceptual framework, emotional attachments and conscious and unconscious desires delimits one's ability to settle 
the meaning of the past". Thirdly, the question is how trauma can be made pedagogical and how the curriculum can be represented in ways so that it opens up possibilities for reparation of traumatic experiences (Britzman 2000: 33-35). In the field of museum pedagogy, Julia Rose (2016) has followed in the psychoanalytical footsteps providing a universal model of learning from what she terms Difficult Histories with a focus on how such stories evoke visitors' feelings of melancholia and loss and how museums can help visitors go through such emotional states and gain self-awareness.

Simon also takes inspiration from Emmanuel Levinas' ethics of face in order to develop the understanding of ethical responsibility arguing $(2014,37)$ that "for a pedagogy of witness to unfold through an exhibition, the images of past events must retain what Emmanuel Levinas referred to as their 'face', their summons, their uncompromising time of otherness. The past in this sense must retain that which does not expend itself as information, in order to teach us and face us as past, in order to be something different than the present". He maintains that an exhibition- e.g. on lynching photographs-not only informs (tells on the level of knowledge transmission), but "arrive in the present making an unanticipated, likely unwanted, claim that may wound and haunt those who have engaged this exhibition"... and does so "through its power to interrupt one's self-sufficiency, demanding an attentiveness that resists reduction to the terms one holds for comprehending and determining the significance of what one sees in the images presented" $(2014,36)$. Difficulties of Difficult Matters, then, become related to the ethical responsibility to respond to the other as being different and the difficulties of such a response.

Discussing pedagogy of trauma (2000) and pedagogy of witnessing (2014) Simon has his point of departure in critical pedagogy (2000), which he also defines as public pedagogy (2014), where engagement in the past in museum exhibitions is connected to contemporary "real world" civic engagement parallel to New Museology (HooperGreenhill e.g. 1994). The article follows this line of thought in Simon's work, yet develops the relational pedagogical and ethical level in order to flesh out the ethics of vulnerability involved.

A difficulty in Difficult Matters detected in museum studies is related to the very communication of these matters in the exhibition - they may be hard to tell about and understand from existing frames of meaning and language-we may lack words and they may appear incomprehensible. Witcomb (2013) suggests that a difficulty in Difficult Matters is about communication of what signifies-ultimately-beyond the limits of existing horizons of meaning, which she finds aspects of Difficult Matters often do. Borrowing Dominique LaCapras' concept of "empathic unsettlement" she defines a kind of empathizing with the suffering of others, which acknowledges the difference of others and suggests a kind of middle road between more conventional ways of communicating cultural history, which allow visitors to understand the represented other and "disrupting techniques"- and here she turns to art-which she finds can illustrate how our understanding of the other can never be complete in order to evoke "empathic unsettlement". With this she argues that various ways of communication must be combined, because they can re-enforce each other. The conceptual framework of the article i.e. combining the notion of vulnerability as a key concept with concepts of Face and Saying/Said elaborates on the understanding of the problems and possibilities of representation of and response to the other on a relational-pedagogical level attentive to the conditions for teaching and learning from difference. 


\section{The Need for a New Approach}

Cameron argues that a change has indeed taken place over the past twenty years:'hot topics such as homosexuality, sexual, racial and political violence, mental illness, massacres, lynching, drugs, terrorism and climate changes are now all part of museological culture", but, in the same breath, she notes that many museums hold back in fear of the consequences (Cameron 2010, 1).

The article contributes to the on-going discussions in museum studies on the self-other relation in regard to exhibitions on Difficult Matters showing how vulnerability can be used as a lever for a relational-pedagogical and ethically sensitive view. The pedagogical view is important, because it offers a basis for approaching the question of transformation. Given the societal role of museums as public educational institutions, the pedagogical view is indispensable. Important studies (Silvén and Björklund 2006; Cameron and Kelly 2010; Williams 2011) help carve out a sociocultural and societal level and argue for the need for social inclusion and responsibility. This way they follow up on important debates in New Museology, but they also dissociates the issue of responsibility from the educational view, which New Museology emphasised (Hooper-Greenhill 1994).

The article re-establishes the line of connection between ethics and pedagogy - that the practice of curatorship and displaying involves a set of pedagogical and ethical issues, which are entangled. It develops the pedagogical and ethical level by taking a close look at the fundamental conditions of possibility for teaching ethics and learning from the other in museum exhibitions in ways, which evoke ethical transformation. Looking at these basic pedagogical and ethical conditions for teaching and for learning, the article takes its point of departure in vulnerability as being inherent to the human condition and as such it is universal and situational (Mackenzie et al. 2014).

When Simon defines Difficult Knowledge as a "terrible gift", because it entails an experience of disturbance and of loss of one's normalised frames of understanding, this definition runs parallel to Silvén and Björklund's idea of Difficult Matters, but Simon situates the "terrible gift" as a pedagogical gift or legacy, because the disturbance it effects is assumed to offer a possibility for a deepened sense of responsibility for the other-which to be sure may be felt as a heavy weight on one's shoulders-but all things considered it is worth receiving (Simon 2005, 2006). The gift, then, ultimately has positive connotationsit is pedagogically productive (offers a needed change) and it is a normative good thing for everyone involved-providing "the opportunity to reconsider what it might mean to make a relation to and with the past, opening us to a reconsideration of the terms of our lives now as well as in the future" (Simon 2006, 189). Simon maintains that exhibiting Difficult Knowledge is a "hopeful practice", because it holds the promise to raise all visitors' consciousness towards a future of democracy and solidarity $(2014,5)$.

Lehrer et al. (2011) use the term Difficult Knowledge discussing "violent pasts in public spaces", yet have primarily a socio-cultural—not pedagogical-perspective on collective knowledge about violent, gruesome, horrific, and painful experiences of e.g. war, genocide, and human rights violations. They define Difficult Knowledge as "knowledge that does not fit, it therefore induces a breakdown in experience, forcing us to confront the possibility that our lives and the boundaries of collective selves may be quite different from how we normally, reassuringly think of them" (Lehrer et al. 2011, 8). This way they correspond to Silvén and Björklund's point of departure. Also, the definition relies heavily upon an "us" and it provokes the question who this "us" is to which Lehrer and Milton refer? Taking the "us" for granted is problematic, because it has an ethical import, which is defined as "us", 
and it demonstrates the need to carve out more carefully a situational perspective in museum studies on Difficult Matters. The ethical problem of generalisation is involved in other interventions into Difficult Matters e.g. Simon (2014) and Rose (2016). Looking at exhibitions on Difficult Matters through the lens of vulnerability allows museum pedagogy to discuss the ethical responsibility involved in self-other relations in exhibitions on Difficult Matters, e.g. how vulnerability is a condition for transformation, yet is lived differently.

In the field of feminist ethics defining vulnerability as a key concept and calling for a reframing of the concept, Erin Gilson defines vulnerability as "a condition of openness... to being affected and affecting in turn" $(2014,310)$ while Adriana Cavarero $(2007,20)$ sees it as a receptivity to "wounding" and to "caring" and both, like Murphy $(2012,86)$, maintain that, consequently there is an ambivalent potentiality of the concept. It is not ultimately something negative to be avoided, but may be an opening to growth and to an involvement in a caring relation to others. In this sense vulnerability is not only "a condition that limits us, but one that can enable us" too (Gilson 2011, 310). The turn to ethics of vulnerability in feminist philosophy is sustained by the assumption voiced by Martha Albert Fineman that "vulnerability presents opportunities for innovation and growth, creativity and fulfilment" $(2012,126){ }^{2}$

The feminist turn to ethics of vulnerability is broad and defined by many different voices. Alyson Cole $(2016,274)$ has criticised this and called for further definition, but she also underscores that the turn to ethics of vulnerability has something very important to say, because it questions conventional understandings of vulnerability as being associated to dependency, passivity, and weakness (and as such as something normally seen as negative) by emphasising the enabling aspects or potentialities of vulnerability. As Cole points out, an important contribution of recent reconfigurations of vulnerability in feminist ethics is how it reveals the dangers and futility of the search for invulnerability (Cole 2016, 274); invulnerability or resilience may affect an ethical closure or insensitivity to the other and her needs.

Re-framing vulnerability, then, seems timely and necessary (Cole 2016), but as Cole calls attention to, it also implies a need to be mindful of how this re-framing of vulnerability by "emphasizing its universality and amplifying its generative capacity" may "dilute perceptions of inequality and muddle important distinctions among specific vulnerabilities" and also imply a risk of neglecting the differences between those who are injurable and those who have already been injured. From this follows that carving out the ambivalent potentiality of vulnerability as a universal condition must always be followed by a sensitivity in museum pedagogy to the meaning of specific vulnerabilities, which would also imply that when acknowledging constitutive vulnerability in regard to exhibitions on Difficult Matters, museum professionals also need to address the possible" concrete injustices" (Cole 2016), which vulnerability may entail in particular situations. In the last section of the article, Judith Butler's norm critical view on precariousness of life is suggested as an axis in debates among museum professionals on situational vulnerability and its concrete manifestations.

\section{Vulnerability in Teaching-Learning Relations in the Museum}

Pedagogical thinkers inspired by Lévinas ground their pedagogical understanding of vulnerability as something inherent and as such a shared human condition of profound import to teaching and learning and therefore it should inspire museum professionals to carefully

\footnotetext{
${ }^{2}$ See also Cole $(2016,263)$ for a summary of some basic notions in feminist ethics of vulnerability.
} 
consider vulnerability as a key concept in museum pedagogy. In the following, the article defines inherent vulnerability as a pedagogical concept with an ambivalent potentiality via the concepts of heteronomy, incarnation and Face plus Saying/Said. From this basis, the article develops the concept of teaching-learning relations in museums and places vulnerability in the centre as the opening to an encounter with the other as being different, which conditions ethical transformation.

\section{Heteronomy}

The educational thinker Ann Strhan, inspired by Lévinas, points out that ethics and evocation of ethical change in pedagogical contexts are not based on an autonomous subjectethical change is not ascribed to self-determination, personal freedom, and morality: "rather than a subject who choses, autonomously, to accept responsibility for others, I am responsible for and to the other person, before I am capable of choice, and only become a subject in heteronomy“(Strhan 2012, 82). Strhan argues for the need to acknowledge the relation of heteronomy as the underlying condition for the freedom of being (Strhan 2012, 81). The etymological definition of heteronomy is to be governed by - or subjected to- the other, which within an ethics of vulnerability would mean that I am demanded by the other to engage in a non-reciprocal relation of responsibility (Strhan 2012, 82). Heteronomy defines the fundamental self-other relation of dependency in pedagogy - a relation in which the learning self is "governed" by the other and thereby vulnerable to the other as a teacher. Thus, teaching and learning is about a relation-a teaching-learning relation-of dependency.

We can define this relational nature of pedagogy further by looking at how Gert Biesta (2013) distinguishes between learning-from and being-taught. Finding that the influence of constructivist learning theory has lead to a notion of teaching as facilitation of learning rather than "a process where teachers have something to give to their students" Biesta connects constructivist ideas to the Socratic idea of teaching as maieutic - a process "immanent to learning" centred on "bringing out what is already there" (Biesta 2013, 449). Instead Biesta suggests that we view teaching in terms of transcendence, i.e. that "teaching brings something radically new to the student" as in a "revelation"-a disclosure of a surprising "truth" inspired by the Other (Biesta 2013). Biesta then argues that teaching thus can be understood as a process of "truth giving", which will also imply that the "gift" of teaching lies beyond the powers of the teacher- "truth" is always a "subjective truth", yet not in a relativistic sense, but as an existential truth-a truth that matters for one's life (Biesta 2013).

From this point of view, the teaching-learning relation is about transcendence of the self through an encounter with the Other revealing something, which was previously secret or unknown in ways, which transform the truths one lives by, one's perceptions of self, others and the world. The museum pedagogical insight to be extracted from this is that the visitor, being taught, is involved in the teaching-learning relation, which makes her vulnerable in the sense that it implies that she transcends the truths she lives by going beyond the limits of existing perceptions towards the previously unknown. Museum professionals as teachers must carefully attend to this vulnerability as an ambivalent potentiality involved in being taught.

Emphasising that teaching matters may be obvious, but in light of the history of New Museology-its confrontation with the education of the Modern Museum as being authoritarian (Bennett 1995) and its response in the form of an overall focus on "learning" (Hooper-Greenhill 1994) - the concept of the teaching-learning relation focuses on the 
need to attend carefully to both poles of the pedagogical entanglement, when considering the vulnerability involved in museum pedagogy in exhibitions on Difficult Matters.

The vulnerability of the teaching-learning relation, which evokes ethical transformation is further defined by the fact that it is centred on an encounter with the Other as being different - non-identic to existing perceptions of self, others and the world. Sharon Todd (Todd 2003, 29) explains that 'teaching is about staging an encounter with the Other, with something outside the self, whereas learning is to receive from the Other more than the self already holds' (Todd 2003, 29). What we can conclude from this is that the teaching in the museum, which happens or is performed in and through the exhibition, must stage an encounter with the Other-something outside the visitors' perceptions, while visitors in order to gain new knowledge must be open to difference. In the space of the teaching-learning relation openness to the encounter with difference, then, is pivotal. This openness, i.e. vulnerability, and the kind of learning it is connected to can be further unfolded via the concept of incarnation.

\section{Incarnation}

Like Biesta, Todd (2015) has defined ethical transformation as grounded in the alteration of the self through an act of "sensible transcendence"- the self transcends itself, its known world. What Todd adds is the notion of transcendence as being based in the sensibility of incarnated being. Transformation is grounded in the sensuous openness of being to the Other.

What is incarnation like? Lévinas describes how the body is "neither an obstacle opposed to the soul, nor a tomb that imprisons it, but that by which the self is susceptibility itself" (OB, 195). It implies the notion that the subject is always incarnated and as such always vulnerable: "the subjectivity of a subject is vulnerability, exposure to affection, sensibility... and exposedness always to be exposed the more" (OB 50). Taking inspiration from Lèvinas, Todd maintains that sensibility of incarnated being is "rooted in a relational context of change and alteration of the subject-a process through which one becomes someone beyond one's previous incarnation" (Todd 2015, 407). Incarnation-and thus the inherent condition of vulnerability-is here intrinsically linked to alteration of the subject due to its fundamental relationality.

From this point of view transformation can be defined as the "alteration of the self", which is grounded in the act in which incarnated, vulnerable being transcends itself, its known world (2015). What Todd then argues is that the distinctive aspect in Lévinas is that he turns the "pedagogical (transformative) moment of subjectivity, with all its sensations, into the very condition of responsibility" (Todd 2015, 414). Transformation, then, is the condition of ethical responsibility_and vice versa: ethical responsibility implies transformation.

Joldersma $(2008,52)$ argues that there is an immediacy of the sensible to incarnated being, which gives rise to a sense of urgency and excitement. This immediacy is ambivalent as it is defined by enjoyment, nourishment, and dwelling in one's world, and vulnerability. On the level of enjoyment, learning is about possessing-mastering the elements of the matter (material, cognitive), and about identifying and associating oneself with something. It is in this process of enjoyment, identifying the exhibit with one self, feeling at home and nourished that the visitor engages with the environment of the exhibit. On this level learning is about assimilation of the subject matter to the known world, to the already existing perceptions of self, others and the world. Learning here is about 
incorporation and understanding. This is also the level of consciousness, awareness of something-be it by the mind or by the body.

Yet, what Joldersma takes from Lévinas is that enjoyment as a process of "possessing" knowledge and including meaning into one's world is also vulnerability, exposure to outside disturbances, which gives learning "an interpretation deeper than assimilation, opening another condition for learning, namely, that learning requires exposure, disturbance, the possibility for rupture" so that because "learning from a teacher requires being influenced by that teacher, then the possibility for being influenced at all requires vulnerability to that influence" $(2008,52)$. As much as learning is about assimilation, it is about the interrupting the subjects- "assimilating complacency" and "disturbance becomes a condition for learning from a teacher, since that requires the possibility of being influenced by that teacher" $(2008,52)$. Also, Joldersma underlines how learning in ways which evoke a critical view and thus implies a transformation of one's perceptions is rooted in the inspiration from the other as demanding one's responsibility in a way, which "changes the nominative 'I' into the vulnerable 'here I am"" $(2008,52)$.

Critical pedagogy, then, begins on a pre-conscious level: "a critical stance towards oneself rides on the possibility of being disturbed by a teacher as other, even before one has the conscious awareness to judge its propriety" (Joldersma 2008, 52). For example, Joldersma emphasises that "listening" as a passive receptivity or openness to an encounter with and inspiration from the Other as teacher "happens" before one can recognize (and judge) the content of that influence and thereby is defined by the vulnerability of uncertainty (Joldersma 2008, 52).

\section{Vulnerability of the Face of History}

Lévinas maintains that ethical responsibility and its transformative potentiality are situated in the encounter "face-to-face" $(2008,202)$ in which the subject experiences proximity-a nearness - to the ethical demand of the other. Yet, defining the other as "Face" (2008), he shows how Face cannot be seen in any straightforward manner in which one gets to know all about the other. Rather, an insurmountable distance, a hiatus, marks the face-to-face. Face is encountered otherwise than in a chronological or historical order-it is "torn up from the world, from horizons and conditions" $(2009,91)$, and it is but "a trace of itself" $(2009,91)$ and expresses itself as an undeniable "presence"- a proximity experienced to the ethical demand of Face-which nevertheless does not mean that Face can be reduced to images or ideas in one's head $(2008,50)$. Face is infinitely other-marked by a "trace of infinity which passes without being able to enter... a trace of an absence, as a skin with wrinkles" $(2009,93)$. That means, Face is irreducible to finite (bounded) entities or categories over which one has power-it is ultimately pre-representational or beyond representation. ${ }^{3}$

\footnotetext{
${ }^{3}$ In connection to the particular pedagogical context of museum exhibition, which involves both human and non-human entities, a question can be raised to the Lévinasian understanding of Face. We must ask if not various objects, mise-en-scenes and design features - and not only human faces — can be the face of history and have a Face to which we have an ethical responsibility to attend and respond in teaching-learning relations in exhibitions on Difficult Matters in order to evoke ethical transformation? Silvia Benso (2000) has developed an ethics of things, in which she argues that there is an alterity-a radical difference or otherness - of things and, accordingly, Benso calls for tenderness-a sensitivity and kindness-to the Face of things. What museum professionals can take from Benso is the ethical need to attend to how material things may have a Face and accordingly how things are involved in teaching-learning relations on Difficult Matters re-saying or re-framing and thus transforming existing understandings.
} 
To museum pedagogy on Difficult Matters this adds to the understanding of representation, i.e. that which is shown, named, and narrated in exhibitions are "merely" the "face of history" as the "Face of history"-its difference-cannot be represented directly or contained in what is said, named, narrated and categorised. In order to understand the "way" of communication of Face, Lévinas develops the concept Face into Saying/Said. He writes, 'Saying is communication, to be sure, but as a condition for all communication, as exposure' $(2009,48)$, and that saying is 'the risky uncovering of oneself, in sincerity, the breaking up of inwardness and the abandon of all shelter, exposure to traumas, vulnerability' $(2009,48)$. Saying is in an intricate relationship with that which Lévinas calls "the said"-with the exchange of information communicated on the level of content, what is present as named, categorised, and defined on the level of meaning making and content in a teaching-learning relation in the exhibition. Saying that signifies interrupts the said, though it remains beyond the content exposed in the said $(2009,48)$. Lévinas inspires to see how a 'reduction' always takes place in the process from the Saying to the Said in communication (2009, 43-44) and thus how representation as communication in pedagogy implies a reduction and that the difference of the other, Face, is vulnerable to our representations of it in exhibition contexts. This insight runs parallel to Witcomb (2013) about the non-representionality of Difficult Matters, but emphasises the ethical and pedagogical challenges and possibilities in relation to teaching-learning relations.

The idea of un-representability is of ethical significance, because it reminds us of our ethical responsibility to see the limits of existing perceptions-how they are bound to a specific time and space - and how our representations are always incomplete and at risk of violating the otherness of the other, who is vulnerable to the meaning we make. It is of pedagogical significance, because it inspires museum professionals to stage a teaching based on a continual questioning of existing perceptions-rather than providing fixed answers and developing methods for saying and re-saying. This, however, implies that museum professionals pay careful ethical attention to how they attempt to involve visitors as vulnerable beings in such teaching-learning relations on Difficult Matters, which may tear a hole in the fabric of existing perceptions, while providing no fixed ground in return.

Lévinasian inspired pedagogy is important to museum pedagogy in exhibitions on Difficult Matters, because it grounds the understanding that relational learning, which evokes ethical transformation of perceptions of self, others and the world is rooted in a relational context of dependency of incarnated, vulnerable being to the inspiration from the other. From this vantage point, ethical transformation in teaching-learning relations can be discussed in connection with exhibitions on Difficult Matters as being difficult. Relational learning is difficult as it implies a relation of dependency on the influence (ethical demand and inspiration) of the other involving the whole incarnated being of flesh and blood in processes beyond cognition. Teaching ethics is difficult because it implies an involvement of the visitor as a vulnerable other and staging encounters with the Face of history, which is vulnerable to the representations and responses of it in exhibition context. Teaching ethics and learning in the museum imply acknowledging the non- or pre-representionality of the other, yet having a sense of proximity to the ethical demand of the other as different and as such inspiring.

Understanding the fundamental conditions for teaching ethics and for relational learning on a pedagogical-ethical philosophical level does not provide fixed answers or a guide to "how to do". Neither does it promise a specific "learning outcome". What it may offer is a fundamental insight into how vulnerability is the basic condition for teaching-learning relations-what they are like, when they concern ethical transformation. 


\section{The Need for a Double Perspective on Vulnerability}

Defining vulnerability, Mackenzie et al. (2014) has developed a taxonomy, which defines vulnerability as inherent to the human condition and as situational (2014). Likewise, Butler (2006) distinguishes between ontological and situational vulnerability — vulnerability as a condition of life (precariousness) and as situational in the specific sense that vulnerabilities are incorporated in specific structures of power (precariousness), which work through social norms. ${ }^{4}$

While pedagogical thinkers inspired by Lévinas can help unfold the pedagogical understanding of the ambivalent potentiality of vulnerability as inherent to the human condition, more attention is needed as to why vulnerability as a condition in teaching and learning is always unfolded in the particular circumstances in which we live a social life together. In this regard the norm critical oriented approach of Butler (2006) can serve as a lever for the situational perspective demanded by e.g. Mackenzie et al. (2014) and inspire discussions on vulnerability on a relational philosophical and normative level in museum pedagogy. Butler's intervention (2006) illustrates how vulnerabilities involved in particular relations are attached to particular sociocultural frames of being and have an ethical import to the unfolding of human life.

\section{Situational Vulnerability and Social Norms}

Butler (2006), discussing vulnerability in terms of precariousness, ${ }^{5}$ maintains it is conditional to the human existence, yet argues that it is situational and responded to differently in public space according to social norms. She argues that there are social norms of vulnerability, which establish hierarchies of vulnerability, meaning that lives are supported and maintained differently across the globe $(2006,32)$. While she appeals to an apprehension of a common human vulnerability, she maintains this should not lead us to ignore how "vulnerability is differentiated, that it is allocated differently" according to social norms $(2006,31)$. This assumption runs parallel to Zembylas' argument in relation to the concept of vulnerability in education, i.e. that we need to acknowledge that "some individuals and groups are clearly more vulnerable than others due to societal structural inequality and this is something that needs to be constantly kept in mind" (Zembylas 2013, 517).

\footnotetext{
4 The double perspective also opens a possibility for bringing the pedagogical understanding of vulnerability into conversation with feminist ethics of vulnerability on the notion of vulnerability as an opeing of being to others enabling a caring relation to others (Gilson 2014). For example, Gilson (2014) argues for the need to displace many of the dichotomies associated with the concept of vulnerability refering to conventional understandings of vulnerability as almost exclusively negative as they are associated to e.g. dependency, passivity and weakness - which Gilson maintans vulnerability need not be. The pedagogical philosophical view developed contributes to the conversation showing that "negative" associations like dependency and passivity can be re-configured and acknowledged as ressources, like heteronomy and passivity entails an enabling "weakening" being —of existing perceptions—which opens the possibility for inspiration and ethical transformation of being.

5 Gilson (2014) finds the concept of precariousness used by Butler is narrower than vulnerability. However, this article use the words synonymously finding precariousness as well as vulnerability associates to events and experiences of uncertainty, risk, danger and unsettlement basically related to human corporality and relationality. It should be mentioned also that Butler (2006) is highly influenced by Lévinas in the work on Precarious Life (2006) disscussed here and connects to the Lévinasian approach to vulnerability in the context of the article.
} 
Who are perceived as vulnerable humans in public space of museum exhibitions? On which normative terms? Butler, attending to sexual minorities, finds that for example intersected people are "often marked by unwanted violence against their bodies in the name of normative notion of what the human must be" $(2006,33)$. Social norms-working intendedly or unintendedly through normative schemes, strategies, action and arrangements-operate according to Butler "not only by producing ideals of the human that differentiate those who are more or less human. Sometimes they produce images of the less than human" $(2006,146)$. Such images of the "less than human" are produced both "in the guise of the human, to show how the less than human disguises itself" and by "providing no image, no name, no narrative, so that there never was a life, and there never was a death" (2006, 146). For example, on a norm critical level leaving out representations (objects, pictures and narratives) of the perpetrator in an exhibition-signals that "there was never a life" or the perpetrator's vulnerability is "less than human", not worth an ethical response.

Are there kinds of vulnerabilities, that should be disrupted? In a North American context, Robin DiAngelo has developed the notion of "white fragility" (2011). He argues that the fragility of white people in North America living in a social environment that protects and insulates them from race-based stress and builds white expectations for racial comfort, while at the same time lowering their ability to tolerate racial stress, needs to be disrupted (DiAngelo 2011, 1). Fragility here appears as a condition of socio-cultural vulnerability, which-if protected and respected-may lead to an exclusion of a caring relation to others.

In the field of feminist ethics of vulnerability it has been argued that the recognition of common vulnerability will lead to an ethical response to vulnerability. For example, Butler takes the shared human condition of vulnerability as a principle by which we vow to protect others from the kinds of violence, we have suffered $(2006,30)$. Yet Murphy charges that there is no guarantee that the recognition of a common human vulnerabilityand accordingly an admission of one's own vulnerability-will "motivate an attempt to respect the vulnerability of others" $(2012,68)$. The Lévinasian perspective add to this conversation that-given the difference of the other-vulnerabilities of others cannot be understood on the basis of one's own experience of vulnerabilities. Rather, one's ethical response must acknowledge that the vulnerability of the other may be very different from what one expects or is familiar with-and then-in this-inspire new perceptions of what it means to be vulnerable.

A critical view on norms in museum pedagogy enables transparency in regard to conceptualisations of vulnerability carried out in exhibitions on Difficult Matters. It makes it possible to museum professionals to critically question and clarify how the exhibition appeals to various experiences of vulnerability and which kinds of transformations an exhibition may possibly inspire. For example, when displaying personal stories of rape exhibitions may present something unexpected or new about the past to visitors, who have been shielded from involvement with such events and experiences, but they may be strangely affirming to viewers who have been e.g. victims of rape. This way, visitors are vulnerable in different ways and accordingly the difficulties involved are not the same for all kinds of viewers. Further, some visitors, who are victims of rape, may experience that the cruelties they have gone through are out in the open and acknowledged, no longer hidden from historical narrative, while others may experience the exhibition as a kind of re-traumatisation, which is distressing in an unwanted way. The ambivalent potentiality of vulnerabilities is defined by the different circumstances in which one finds oneself. Museum professionals have an ethical responsibility for carefully considering the 
vulnerabilities involved in particular pedagogical circumstances of exhibitions on Difficult Matters.

In museum studies, the discussions on exhibitions on Difficult Matters are generally broad and often lack attention to the social norms of vulnerability involved in teaching and learning from Difficult Matters. For example, Lehrer and Milton assert that difficult knowledge "induces a breakdown in experience, forces us to confront the possibility that the conditions of our lives and the boundaries of our collective selves may be quite different from how we normally, reassuringly think of them" ( Lehrer et al. 2011, 8). From the point of view of situated vulnerability and orientation to social norms, the question must be: who is the "us" here? The appeal to "us" reveals the underlying assumption that museum visitors are not people whose lives may already be far from reassuring, may already be very vulnerable. The assumption seems to be that the museum visitor is not someone, who has already experienced first-hand the violence, brutality, and trauma that is exhibited in the museum.

When Lehrer and Milton continue elaborating on difficult knowledge as the kind of knowledge that "points to more challenging, nuanced aspects of history and identity potentially leading us to re-conceive our relationships with those traditionally defined as others" (Lehrer et al. 2011, 8), then once again we have to ask-who are these visitors, whose sense of self is supposedly unsettled by a confrontation with Difficult Matters? Most likely not those who have already encountered these same Difficult Matters in their daily lives and to whom these matters are thus no surprise at all? This perspective is essential to the argument about vulnerability as a key concept: is it justifiable to ask those who are already thoroughly aware of their vulnerability (because of poverty, racialization, immigration status, etc.) to open themselves to an encounter with the other, when that other may be the very person who renders them vulnerable in their daily lives? Museum professionals cannot leave out considerations on situational vulnerability if the exhibitions on Difficult Matters that the museums create and ask visitors to learn from are the very ones that create situational vulnerability to some. Clearly, situational vulnerability positions museum visitors unequally. Here, it is relevant also to remember that-in the responsibility for the visitor as the other and as such as different- the museum professional cannot ask from the visitor what she asks from herself.

\section{Vulnerability as a Key Concept in Museum Pedagogy}

Situating vulnerability as a key concept in museum pedagogy calls for a new approach to the difficulties of Difficult Matters in the context of museum exhibitions. What is difficult is about a pedagogical relation and the pedagogical questions concerning the ambivalent potentiality of vulnerability as an opening to ethical transformation it entails. When teaching ethics museum professionals have an ethical responsibility for the vulnerability of the visitor-and the face of history-which may be seen as being difficult, because it involves ethical considerations often of a mixed nature-and contradictory possibilities for growth and harm, which cannot be easily answered or finally determined. Vulnerability is an ambivalent potentiality for being-taught, which may imply growth — and violence-and as such it is a difficult condition for relational learning, which demands ethical attention.

Together, the pedagogical philosophical and ethical view on the fundamental inherent condition of vulnerability and the norm critical view on vulnerability put forward for consideration in the article contribute to an understanding of the difficulties of teachinglearning relations as related to the ambivalent potentiality of the concept of vulnerability. The ambivalent potentiality of vulnerability concerns both how the condition of 
vulnerability as being inherent and situational involves pedagogical ethical challenges and possibilities and how the use of the concept in museum practice demands ethical sensitivity. The ambivalent potentiality of vulnerability requires museum professionals to think carefully about whose vulnerabilities are supposed to be an opening for growth. Which kinds of vulnerabilities are acknowledged? On what terms? Whose normalised frames of understanding are considered in need of ethical transformation through openness to the other?

The teaching-learning relation can be defined as the "contact zone" for the pedagogical encounter with the other as different-infinitely beyond existing horizons of meaning. Also, teaching-learning relations in exhibitions on Difficult Matters are integral part of existing horizons of meaning as they are permeated by social norms. The teaching-learning relation connects the inspiration from the other and existing perceptions and is a zone where perceptions of self, others and the world are both established and re-established. From this vantage point, the turn to ethics in museum pedagogy does not imply that we minimize the political aspects. The insight to be extracted from New Museology is that the educational relation between museum and visitor is charged by the question of power (e.g. Hooper-Greenhill 1994) — an insight re-occurring in museum studies on Difficult Matters (e.g. Camron and Kelly 2010). Placing vulnerability as a key concept in museum pedagogy implies ethical attention to what the fundamental self-other relation is like, when it is ethical. It implies the acknowledgement that ethical responsibility for the other and the vulnerability which conditions it is the foundation of knowledge, judgement and political activity.

Developing a double perspective on vulnerability as a condition, defining ethical transformation as a leitmotiv in exhibitions on Difficult Matters, and connecting museum pedagogy to an action-oriented norm critical approach offers a way out of the risk of "empty empathy" entailed in education on Difficult Matters (Zembylas 2014). It prompts museum professionals to question the ways in which exhibitions may disturb and affect visitors and discusses how Difficult Matters can be made pedagogically productive in ethical ways - mindful of the ambivalent potentialities of the vulnerabilities involved.

Open Access This article is distributed under the terms of the Creative Commons Attribution 4.0 International License (http://creativecommons.org/licenses/by/4.0/), which permits unrestricted use, distribution, and reproduction in any medium, provided you give appropriate credit to the original author(s) and the source, provide a link to the Creative Commons license, and indicate if changes were made.

\section{References}

Acuff, Joni Boyd, and Laura Evans (eds.). 2014. Multiculturalism in Museums Today. Lanham: Rowman \& Littlefield.

Andersson, David. 2005. New lamps for old: Museums in the learning age. Paper presented at museums Australia conference in Sydney, Australia.

Bennett, Tony. 1995. The birth of the museum: History, theory politics. London: Routledge.

Benso, Silvia. 2000. The face of things: A different side of ethics. Albany: State University of New York Press.

Biesta, Gert. 2013. Receiving the gift of teaching: From 'learning from' to 'being taught By'. Studies in Philosophy and Education 32(5): 449-461.

Bourdieu, Pierre, and Alain Darbel. 1991. The love of art. European art museums and their public. Cambridge: Polity Press.

Britzman, Deborah P. 1998. Lost subjects, contested objects: Toward a psychoanalytic inquiry of Learning. Albany: State University of New York Press. 
Britzman, Deborah P. 2000. If the story cannot End: Deferred action, ambivalence and difficult knowledge. In Between hope and despair: The pedagogical encounter of historical remembrance, ed. R.I. Simon, S. Rosenberg, and E. Eppert, 27-57. Lanham: Rowman \& Littlefield.

Butler, Judith. 2006. Precarious life the powers of mourning and violence. London: Verso.

Cameron, Fiona. 2010. Introduction. In Hot topics, public culture, museums, eds. Cameron Fiona and Kelly Lynda, 1-15. Newcastle upon Tyne: Cambridge Scholars Publishing.

Cameron, Fiona, and Lynda Kelly (eds.). 2010. Hot topics, public culture, museums. Newcastle upon Tyne: Cambridge Scholars Publishing.

Cavarero, Adriana. 2007. Horrorism: Naming contemporary violence. New York: Columbia University Press.

Chinnery, Ann. 2012. Temple or forum? On the museology and education for social change. In Philosophy of education., ed. C.W. Ruitenberg, 269-276. Urbana, IL: Philosophy of Education Society.

Clifford, James. 1997. Routes: Travel and translation in the late twentieth century. Harvard: Harvard University Press.

Cole, Alyson. 2016. All of us are vulnerable, but som are more vulnerable than others: The political ambiguity of vulnerability studies, an ambivalent Critique. Critical Horizons A-Journal of Philosophy and Social Theory 17: 260-277.

DiAngelo, Robin. 2011. White fragility. International Journal of Critical Pedagogy 3(3): 54-70.

Duncan, Carol. 1995. Civilizing rituals. London: Routledge.

Dudley, Sandra H. (ed.). 2010. Museum Materialities-Objects, Engagements interpretations. London: Routledge.

Falk, John H., and Lynn D. Dierking. 1992. The museum experience. Washington: Whalesback Books.

Falk, John H., and Lynn D. Dierking. 2013. The museum experience Revisited. Walnut Creek: Left Coast Press Inc.

Fineman, Martha Albertson. 2012. 'Elderly' as vulnerable: rethinking the nature of individual and societal responsibility. Emory Legal Studies Research Paper No. 12-224 101-42.

Gilson, Erinn. 2014. The ethics of vulnerability: A feminist analysis of social life and practice. New York: Routledge.

Hein, George E. 1998. Learning in the museum. London: Routledge.

Hein, Hilde. 2011a. The responsibility of representation. A feminist perspective. In The Routledge companion to museum ethics. Redefining ethics for the twenty-first-century museum, ed. J. Marstine. London: Routledge.

Hein, Hilde. 2011b. Looking at museums from a feminist perspective. In Gender, sexuality and museums. A Routledge reader, ed. A.K. Levin. London: Routledge.

Hooper-Greenhill, Eilean (ed.). 1994. The educational role of the museum, 1st ed. London: Routledge.

Hooper-Greenhill,. 2007. Museums and education purpose, pedagogy, performance. London: Routledge.

Janes, Robert R. 2007. Museums, social responsibility and the future we desire. In Museum revolutions: How museums change and are changed, ed. Simon J. Knell, Suzanne Macleod, and Sheila Watson, 134-146. London: Routledge.

Johansson, Christina. 2015. Museums, migration and cultural diversity: Swedish museums in tune with the times?. Innsbruch: StudienVerlag.

Joldersma, Clarence W. 2008. The importance of enjoyment and inspiration for learning from the teacher. In Levinas and education. At the intersection of faith and reason, ed. Denise Egéa-Kuehne, 43-56. London: Routledge.

Kidd, J., S. Cairns, A. Drago, A. Ryall, and M. Stearn (eds.). 2014. Challenging history in the museum: International perspectives. Farnham: Ashgate.

Leahy, Helen Rees. 2012. Museum bodies. The politics and practices of visiting and viewing. TLondon: Routledge.

Lehrer, Erica, Cynthia Milton, and Monica Eileen Patterson (eds.). 2011. Curating difficult knowledge. Violent pasts in public places. New York: Palgrave Macmillan Memory Studies.

Lévinas, Emmanuel. 2008/1961. Totality and Infinity. An Essay on Exteriority. Pittsburgh: Duquesne University Press. Translated from the French by Alphonso Lingis. Originally published in French in 1961 under the title Totalité et infini. Essai sur 1'extérioité Den Haag: M. Nijhoff.

Lévinas, Emmanuel. 2009/1974. Otherwise than Being or Beyond Essence Pittsburgh, Pennsylvania: Duquesne University Press. Translated from the French by Alphonso Lingis. Originally published in French in 1974 under the title Autrement qu'être ou au-delá de 1'essence Den Haag: M. Nijhoff.

Macdonald, Sharon. 2009. Difficult heritage: Negotiating the nazi past in Nuremberg and Beyond. London: Routledge.

Mackenzie, Catriona, Wendy Rogers, and Susan Dodds (eds.). 2014. Vulnerability: New essays in ethics and feminist philosophy. Oxford: Oxford University Press. 
Murphy, Ann V. 2012. Violence and the philosophical imaginary. Albany: State University of New York Press.

Rose, Julia. 2016. Interpreting difficult history at museums and historic sites. Lanham: Rowman and Littlefield.

Sandell, Rickard. 2003. Social inclusion, the museum and the dynamics of sectoral change. Museum and Society 1 (1): 45-62.

Sandell, Rickard. 2011. On Ethics, activism and human rights. In The routledge companion to museum ethics. Redefining ethics for the twenty-first-century museum, ed. Janet Marstine, 129-145. London: Routledge.

Silvén, Eva, and Anders Björklund. 2006. Detecting difficulty. In Svåra Saker: Ting och Berättelser som Upprör och Berör, ed. Eva Silvén, and Anders Björklund. Stockholm: Nordiska Museet.

Simon, Roger I. 2005. The touch of the past: Remembrance, learning, and ethics. New York: Palgrave Macmillan.

Simon, Roger I. 2006. The terrible gift: Museums and the possibility of hope without consolation. Museum Management and Curatorship 21(3): 187-204.

Simon, Roger I. 2011. 'The turn to pedagogy: A needed conversation on the practice of curating difficult knowledge. In Curating difficult knowledge: Violent pasts in public places, ed. E. Lehrer, C.E. Milton, and M.E. Patterson, 193-210. New York: Palgrave Macmillan.

Simon, Roger I. 2014. A Pedagogy of witnessing: Curatorial practice and the pursuit of social justice. Albany: State University of New York Press.

Simon, Roger I., Sharon Rosenberg, and Claudia Eppert (eds.). 2000. Between hope and despair: Pedagogy and the remembrance of historical trauma. Lanham: Rowman \& Littlefield.

Strhan, Ann. 2012. Lévinas, subjectivity, education. Oxford: Wiley Blackwell Publications.

Todd, Sharon. 2003. Learning from the other. Lévinas, psychoanalysis, and ethical possibilities in education. Albany: State University of New York Press.

Todd, Sharon. 2015. Education incarnate. Educational Philosophy and Theory 48(4): 405-417.

Vergo, Peter. 1989. The new museology. London: Reaction Books.

Watson, Shiela. 2016. Why do Emotions Matter in Museums and Heritage Sites? In Sensitive pasts: Questioning heritage in education, ed. Carla van Boxtel. Oxford: Berghahn Publishers.

Williams, Paul. 2011. Memorial museums and the objectification of suffering. In The routledge companion to museum ethics, ed. Janet Marstine, 220-236. London: Routledge.

Witcomb, Andrea. 2010. The politics and poetics of contemporary exhibition making: Towards an ethical engagement with the past. In Hot topics, public culture, museums, eds. Cameron Fiona, and Kelly Lynda, 245-264. Newcastle upon Tyne: Cambridge Scholars Publishing.

Witcomb, Andrea. 2013. Testimony, memory and art at the Jewish Holocaust museum, Melbourne, Australia. In Museums and communities curators, collections, collaborations, ed. Viv Golding, and Wayne Modest, 260-274. London: Bloomsbury.

Zembylas, Michalinos. 2013. The crizis of "pity" and the radicalization of solidarity: Toward critical pedagogies of compassion. Educational Studies 49(6):504-521.

Zembylas, Michalinos. 2014. Theorizing “difficult knowledge' in the aftermath of the 'affective turn': Implications for curriculum and pedagogy in handling traumatic representations. Curriculum Inquery 44(3):390-412. 